\title{
Mobility and Protected Areas in the Alps
}

\author{
Regula Imhof, Michael Vogel, Gérard Ruiz
}

Keywords: mobility, Alps, tourism, protected areas

\section{Abstract}

Of the 95 million annual tourists estimated in the Alps (confirmed by the Working Group Transport of the Alpine Convention, October 2008), around $80-85 \%$ use their private car to reach the desired destination, thus deepening the impact of traffic on man and nature in the Alpine Space. Public transport could be a solution for decreasing the negative effects of traffic in line with the goals of the Alpine Convention, but public transport is in direct competition with the advantages of using a private car.

The Alpine Convention aims at reducing the negative effects and risks of transport. It is considering all possible modes of transport and how best to combine them, working on the principles of precaution and identifying the causer and proposes a coordinated transport policy of the parties to the Convention.

In recent years there has been a paradigm change for access to protected areas, when these areas invested in mobility planning and management, not only in the parks and protected areas themselves but also in means of transport for the visitors right from the start of the journey to their destinations. The development of special packages and offers for visiting protected areas by public transport is one of the most effective instruments for motivating visitors to change their attitude towards the use of private transport. In line with its basic orientation towards "protection", transport and mobility management in parks and protected areas is an important issue for the sustainable use and development of parks and protected areas as well for controlling the flow of visitors through the park. In addition to this basic interest of parks and protected areas in sustainable development, public transport management allows the park administrations to involve the local population in the park management and creates ownership as well as deeper understanding for the basic principles of sustainable development of a region. Local people can provide transport services to the visitors with small buses, collective taxis or alternative means of transport such as horse-drawn carriages. If the packages are to succeed in motivating visitors to travel by public transport, they have to be affordable, attractive and widely advertised. Partners in projects involving long-distance travel are often the railway companies, tourist organizations, communities and regions who are called upon to offer a "mobility guarantee" to the clients for the entire length of their journey. This guarantee includes travel from the starting point to the destination as well as mobility once they have arrived. Increasingly such a two-stage guarantee is seen not only as an exceptional offer to visitors but is also becoming a crucial marketing element for destinations, parks and protected areas.

\section{Introduction}

The introduction of the article refers mainly to the Report on the State of the Alps: Transport and Mobility of the Alpine Convention, published in 2007.

\section{Tourism in the Alps}

The figures on annual tourists in the Alps vary from 60 million annual holiday guests (Bätzing 2003) to 95 million annual tourists (confirmed by Working Group Transport of the Alpine Convention 2008).In his statement Bätzing calculates that you have to add another 60 million day tourists to the 60 million holiday guests. About 370 million overnight stays make the Alps the largest holiday region in Central Europe (Bätzing 2003). Although the economic significance of tourism in the Alps is sometimes overestimated, it is a key industry for many alpine areas. About $10 \%$ of the alpine municipalities feature a tourist monostructure (Bätzing 2003). Based on good natural and infrastructural conditions (i.e. sufficient snow cover), tourism here dominates the whole local or regional economy. The majority of tourist overnight stays are registered during the summer. Nevertheless winter tourism is economically more important in many places due to the higher spending of winter tourists (Bartaletti 1998).

\section{A driving force behind traffic}

In general, changing leisure and tourist trends affect passenger transport. Within the Alps, the growth of leisure and tourist demands is expected to generate an increase in individual motorized transport in particular. This is the most common form of transport used by tourists in many parts of the Alps where there is a severe lack of public transport suited to tourist requirements. The European Environment Agency estimates that up to $80 \%$ of all tourist journeys to the Alps are by car (EEA 2003). In Austria the number of tourist arrivals by car amounts to $85 \%$ (Rauh et al. 1998). In Italy the number of tourist arrivals by car amounts to $97 \%$ (confirmed by Working Group Transport, October 2008). 


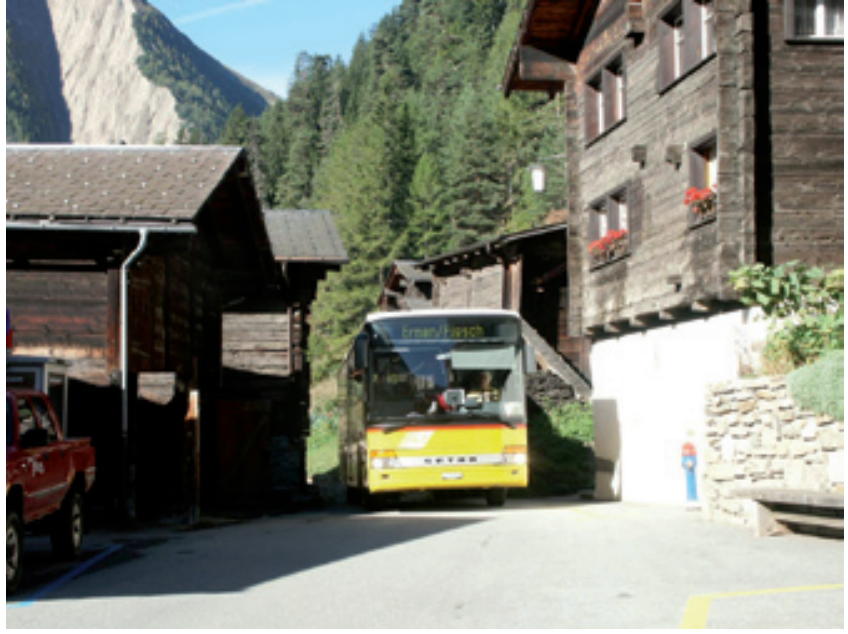

"Bus Alpin”, new shuttle bus for public transport to guarantee mobility to the starting points of mountain journeys (C) Andreas Weissen

Day tourism

In Germany and Switzerland, about $40 \%$ of all journeys (and $45 \%$ of all distances covered) are for leisure purposes. In the near future, leisure transport in Germany is expected to increase by $30 \%$. As the majority of leisure journeys are made by cars, this will lead to an increased incidence of individual motorized transport (IFO 2000; DIW \& INFAS 2004; BMVIT 2002; ARE \& BFS 2001). From an environmental point of view, cars - after planes - exert the highest pressure on the environment (Gössling-Law \& Peeters 2007). For the Alpine Space, the developments outlined above imply, for example, the risk of growing emissions of air pollutants and noise as well as the risk of increasing land take for infrastructure.

Measuring tourism, traffic and their interrelations

The intensity of tourism is usually defined by the number of beds in accommodation businesses per resident population. In France not only the "official" tourist sector is of importance, a large share of tourist accommodation is offered as private second homes. During the past two decades almost 335000 new second homes were built across the whole of France. Second homes here represent 73\% of the total tourist lodging capacity, and $18 \%$ of all nights spent by French residents in 1999 were in their second home (EEA 2003). Generally France holds the "world record" with 3 million second homes (10\% of all accommodation). About $28.4 \%$ of these second homes are situated in alpine regions of PACA and

\section{$\operatorname{lnfobox}$}

Tourist transport refers to all transport related to vacations and holidays. It comprises the distances travelled to and from holiday destinations as well as the journeys taken during the holiday itself. According to the WTO definition "tourism" also includes business journeys. However, "tourist transport" in this article refers only to transport undertaken for holiday purposes.
Rhône-Alpes. In Switzerland and Italy too, beds in second homes are supposed to play a role in gauging tourism intensity (Bätzing 2003), but the relevant data to describe the situation are not available.

The importance of tourist demand in the Alps, described as absolute figures of tourist nights spent in tourist accommodation, varies considerably between the alpine countries. However, in order to draw conclusions on the development of traffic, the relative description of tourist demand is more meaningful.

\section{Development of tourist demand}

Generally speaking, the statistics show an increase in the number of overnight stays and tourist arrivals between 1996 and 2005. In terms of average duration, tourist stays tend to get shorter.

So in the Alps a weak trend towards shorter but more frequent holidays is visible between 1996 and 2003. This is in line with the developments observed by the European Environment Agency for the whole of Europe. People tend to use the increased length of their vacations for multiple holiday stays instead of having one long holiday (EEA 2003). In terms of transport, tourists travelling more often to alpine destinations and staying for shorter visits imply a growth in traffic volumes. Since tourists in the Alps arrive mostly by car, this applies in particular to individual motorized transport.

\section{Tourism and traffic volumes}

Although less than $10 \%$ of all distances covered are for tourist reasons, tourist travel can cause extensive traffic volumes on certain routes. For instance, about $55 \%$ of all trans-alpine journeys in Switzerland relate to holidays and vacations. An additional $29 \%$ of the journeys are for leisure purposes, including day and short tourist trips (ARE 2003). Relevant results of interviews and surveys are not available for the whole alpine region. However, the importance of tourism and leisure-related transport can also be interpreted by figures on traffic volumes from the transport sector, in particular by their seasonality and the occurrence of peak volumes.

\section{Methodology}

\section{RSA 1}

The conference in Garmisch-Partenkirchen in 2004 formulated the mandate to the Permanent Secretariat to create the first report on the state of the Alps. For the first report on "Transport and Mobility", data were collected at national level, from projects and at European level, harmonized and analysed for the Alpine Space. National groups of experts from Austria, Germany, Italy and France took on the responsibility for individual chapters of the report. The report was adopted at the conference in Alpbach in November 2006 and published in 2007 in all alpine languages. It draws conclusions on the alpine transport system, 
driving forces of mobility and transport, effects of transport and mobility in the Alps, alpine-relevant transport policies and cooperation in the Alps, conclusions and synthesis in view of sustainable mobility and the main challenges for the future. The present article refers to relevant information and conclusions on transport and tourism of the report.

\section{The tasks of the Working Group Transport of the} Alpine Convention

The Working Group Transport operates on the basis of a mandate of the alpine environment ministers. The most recent mandate of the Alpine Conference in Alpbach emphasizes the effects of transport caused by tourist activities and requested the Working Group to analyse the situation as well as to collect examples of good practice and develop approaches to increase the share of public transport in long-distance travel for tourist purposes. Within the framework of this task the Working Group installed a sub-working group "Soft Mobility" and studied the situation in every alpine country. This study was presented during a seminar in Bonn, June 26 and 27, 2008, using this opportunity to support the cooperation among tourist operators.

\section{Learning from good practice in the parks}

In spring 2008, good practices on sustainable mobility in protected areas were collected using a questionnaire. The description indicates the name of the good practice, the protected area and the country, background information on the initial situation, the objectives and the motivation for the activity. Furthermore, information on the project time frame, the target group, the stakeholders, the type of operation and the means of transport as well as on financing was collected. Finally the transferability as well as the product and process innovation was analysed. The key aspects shall give an indication of the success of the project. These good practices have been published in a brochure and on the websites of ALPARC.

\section{The seminar in L'Argentière - la Bessée}

The seminar was organized by the Task Force Protected Areas of the Permanent Secretariat of the Alpine Convention for the network of protected areas (ALPARC) in collaboration with the French Ministry for Ecology, Energy, Sustainable Development and Spatial planning (MEEDDAT). The goal of the seminar was to discuss the requirements and innovative perspectives for the access to alpine protected areas with the help of identified good practices. Main topics were the means of transport, organizational questions, tourist products (access to protected areas) and regulations. The examples of good practices were presented by the Parc National des Ecrins, Parc National de la Vanoise, Nature Park Logarska Dolina, Nationalpark Berchtesgaden and Naturpark Weissbach, Landschaftspark Binntal, Parc Naturel Régional du Verdon, Parc

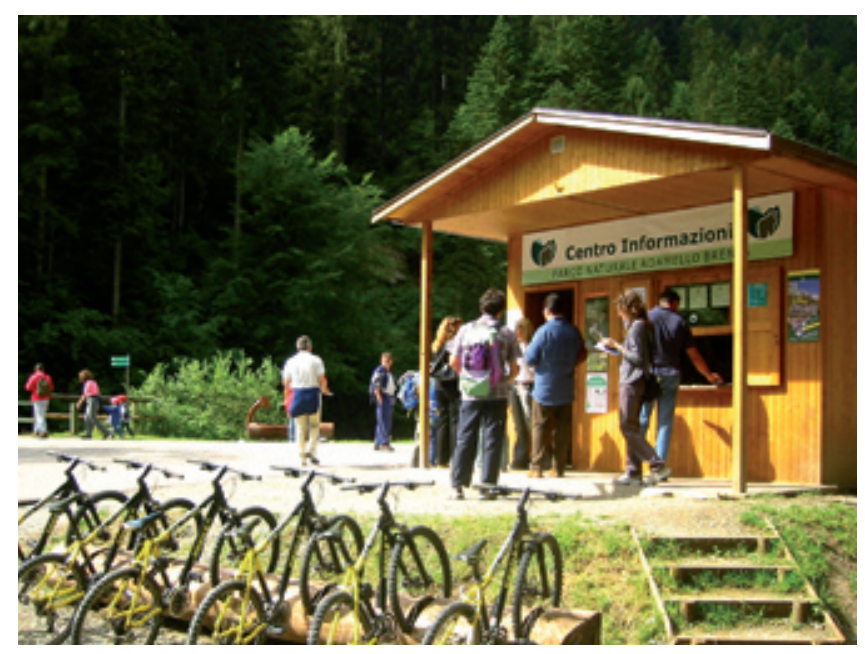

Info centre in the Parco Naturale Adamello Brenta at a bus stop of the park shuttle bus with information on mountain journeys and bike rental (Italy); trains, shuttle buses and coaches replace the private car, the alpine protected areas promote soft mobility (C) Photoarchiv Naturpark. Adamello - Brenta

Naturel Regional du Queyras, Nationalpark Hohe Tauern, Parco Nazionale Gran Paradiso and the Parco Naturale Adamello Brenta. These good practices serve as concrete examples and important reference for this article.

\section{Results and Discussion}

Tourism in parks and protected areas

Tourism and recreation are an important issue in protected areas. In most of these areas, in fact, especially in national parks, the number of visitors is increasing. This can be described as the result of growing interest in nature and landscape-based recreation. Consequently it becomes ever more important to manage these activities. In doing so, measures must be based on well-founded data as well as widespread knowledge

\section{$\operatorname{lnfobox}$}

Main findings of the Report on the State of the Alps of the Alpine Convention "Transport and Mobility", 2007

\section{Status}

Traffic related to tourism and day tourism has a strong influence on traffic volumes within the Alps, in particular with respect to peak situations. Alpine roads suffer from high traffic volumes connected with the journeys to and from tourist destinations within and outside the Alps - both in winter and in summer.

Trends

The trend towards shorter but more frequent holidays can also be observed in the Alps. This implies a growth of individual motorized transport. The main tourist centres in the Alps do not solely depend on the close vicinity of major transport infrastructures. On the contrary, some tourist centres are situated in rather remote areas.

\section{Hot issue}

Measures need to be taken to increase the use of public transport for journeys to and from tourist destinations and especially during the stay at the holiday destination. 


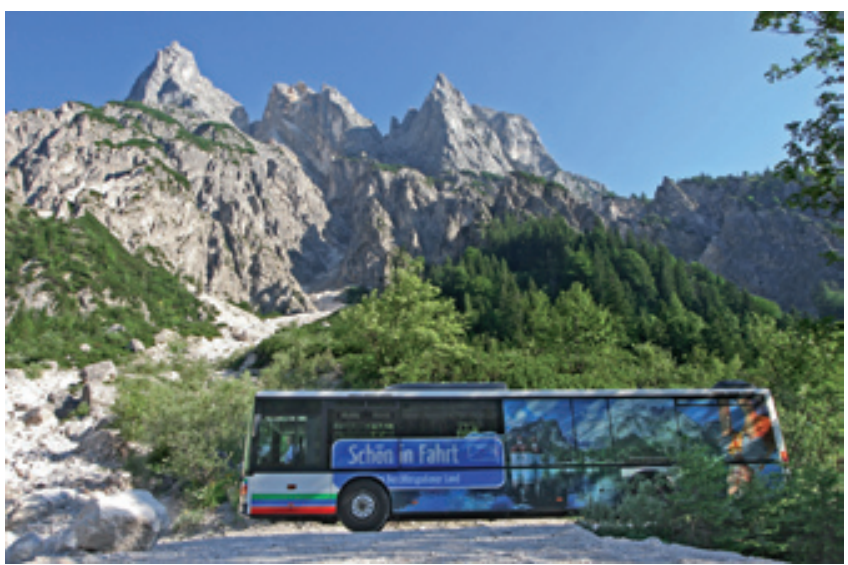

Coach running between Berchtesgaden Nationalpark and Naturpark Weissbach (Germany); trains, shuttle buses and coaches are replacing private cars, the alpine protected areas promote soft mobility (C) Regionalverkehr Oberbayern GmbH

and understanding of recreation. Associated investigations must not only focus on visitors (Hennig \& Künzl 2005). Attention must also be paid to infrastructure, nature and landscape-compatible activities as well as the stakeholders. Another aspect is the need to incorporate protected areas in a larger planning framework (see Hannemann \& Job 2003). All too often, parks and protected areas are regarded as something apart from the surrounding regions, but tourism and recreation in parks cannot be regarded separately from their surroundings.

\section{Demands for that include:}

- no short-term commercial exploitation but a permanent increase of value.

- no "selling off the family silver" but instead using heritage in a more productive future-oriented manner. not only increasing value but lasting added value instead of increasing tourist utilization, more and lasting protection.

- The utilization of protected areas for tourism under provisions must imply:

- master plans for tourist development within a coordinated regional development.

- That means the integration of local, municipal and regional needs and requirements.

- drawing up and supporting all measures for a practical and useful visitor management.

- That means spatial and temporal steering and control of visitor streams as well as taking measures for

\section{$\operatorname{lnfobox}$}

The overriding target must therefore be to develop a well-ordered tourism in line with the preservation of natural and cultural assets and local economic development.

Conservation and tourism are no longer in conflict with each other like "fire and ice" and the challenge must be to link the common understanding of the value of natural assets with the goals of sustainable development. Ecological and economic objectives must be combined. renovating and re-naturalizing used tourist zones. drawing up and supporting a staggered protected area policy inside holiday destinations with strictly defined guidelines for protection and utilization.

drawing up and supporting measures for increasing the value of natural areas by a strategy of "protection through controlled use". (see Iwand et al. 2002)

That means connecting nature conservation and added economic value through well-adjusted levels of utilization, especially in large areas like national parks, nature parks and biosphere reserves. The support as well as cooperation and participation of local communities and regions is essential in the generation and implementation phase of development processes. In addition, joint thinking on concepts for financing and supporting achievements through networking and building public-private partnerships are required (Revermann \& Petermann 2002).

Mobility goals for tourism and management of protected areas within the framework of the Alpine Convention are a general reduction of the negative effects and risks of transport, considering all modes of transport and the best possible combination of different means of transport, principles of precaution and causer principle and the framework convention requests a coordinated transport policy of the parties.

\section{Transport Protocol}

The general aim of the protocol to which the parties have agreed is to implement a sustainable transport policy, which decreases the risks of the inner-alpine and trans-alpine transport on a level which is tolerable for human beings, animals and plants as well as for habitats. At the same time such a policy should contribute to the development of the living and economic sphere in the Alps. Main tools and means are increasing the effectiveness and efficiency of the transport systems and improving the means of transport while taking into account resources under economically viable costs under fair economic conditions for the individual means of transport.

\section{Tourism Protocol}

Article 13 (Tourist traffic and Transport) states that, "the Contracting Parties have agreed to pursue a sustainable transport policy which will reduce the negative effects of and risks posed by intra-Alpine and transalpine transport to a level which is not harmful to people, flora and fauna and their environments and habitats."

\section{Nature Protection Protocol}

The Contracting Parties undertake to preserve, manage and, where necessary, to extend the existing protected areas (...) and also to define, where possible, new protected areas. They shall pursue the measures appropriate for creating a national and crossborder network of 
protected areas. They shall take all appropriate measures to avoid impairing or destroying protected areas and shall reduce or prohibit any form of use incompatible with the ecological processes of these areas.

\section{Conclusions}

Following the statements of existing regulations, the aims formulated in the first Report on the State of the Alps on Mobility and Transport and the expert conference "Environmentally-friendly travel in Europe" 2006, and the experiences of the parks and protected areas, the following needs for an increasing share of public transport used by tourists have been identified:

Transport between the starting point and the destination:

- guaranteed easy accessibility by public transport of tourist destinations in the Alps from all European countries

- cross-border packages and information systems for luggage, integrated tariff systems, combined offers (public transport and bicycle, etc.)

Transport at the destination:

- ensuring mobility of tourists at their destination in the Alps with attractive public transport

- mobility management, offers without private car

Others:

- developing offers, incentives and information systems for the effective promotion of sustainable mobility

- levelling out peak traffic loads by staggering holidays in Europe and promoting appropriate offers in alpine tourism

- strategic partnership between tourist operators and transport companies

appropriate marketing

Assuming that of the 95 millions annual tourists estimated in the Alps (confirmed by the Transport Working Group of the Alpine Convention) around 80-85\% use their private car to reach the desired destination, public transport is in direct competition with the use of private vehicles. A direct correlation between the quality of protection in an area and the kind of mobility has been recognized. Parks and protected areas have competent personnel for raising awareness, setting up ecobalances etc. and the experience of the parks in managing transport caused by tourist traffic is also useful in the larger context of transport management linked with tourism (in terms of being located in border regions of the Alps and regional planning management in general). There is an increasingly important role for the parks in education and raising awareness, involving the local population (a win-win situation in terms of quality and services), setting up environmental balances with a special focus on parks and environmentally friendly means of transport. This means taking economic, social and ecological aspects into account; evaluating alternative means of transport such as mountain cableways; coherent and integrative management involving the different stakeholders and actors and developing packages and offers that include transport. By the basic orientation of their concepts and goals, by their competences and rich experiences, the parks are sufficiently legitimated to support the development of sustainable mobility also outside their "territory" and request target-oriented measures from the relevant decision-makers and institutions.

\section{References}

ARE - Bundesamt für Raumentwicklung, BFS - Bundesamt für Statistik (ed.) 2001. Mobilität in der Schweiz: Ergebnisse des Mikrozensus 2000 zum Verkehrsverhalten. Bern, Neuenburg.

ARE - Bundesamt für Raumentwicklung (ed.) 2003. Alpen- und grenzquerender Personenverkehr 2001. A + GQPV 01, Schlussbericht. Bern.

Bartaletti, F. 1998. Tourismus im Alpenraum - Eine alpenweite Bilanz. Praxis Geographie. 2. Braunschweig, Bätzing, W. 2003. Die Alpen - Geschichte und Zukunft einer europäischen Kulturlandschaft. München.

BMVIT - Bundesministerium für Verkehr, Innovation und Technologie (ed.) 2002. Verkehr in Zablen. Wien. Hannemann, T. \& H. Job 2003. Destination "Deutsche Nationalparke" als touristische Marke. Zeitschrift für Tourismus, 58: 6-17.

(BMVIT - Bundesministerium für Verkehr, Innovation und Technologie (ed.). Umweltfreundlich Reisen in Europa. Herausforderungen und Innovationen für Umwelt, Verkehr und Tourismus. Proceedings of the conference on environment friendly travelling. Vienna, 30.-31. January 2006. Available at: http://eco-travel. webwork.info/presse-downloads/Broschuere_deutsch. pdf (accessed: 29/09/06)

Conference 2006. Declaration on climate change. Document IX/07/1. Available at: http://www.bmu.de/ files/pdfs/allgemein/application/pdf/deklaration_alpenkonferenz_klima.pdf (accessed: 20/03/07)

DIW - Deutsches Institut für Wirtschaftsforschung \& INFAS - Institut für angewandte Sozialwissenschaft Gmbh (ed.) 2004. Mobilität in Deutschland Ergebnisbericht. Available at: http://daten.clearingstelleverkehr.de/196/10/mid2002_ergebnisbericht.pdf (accessed: 6/17/06)

EEA - European Environment Agency (ed.) 2003. Europe's Environment - The Third Assessment. Copenhagen. Elsasser, H. \& R. Bürki 2005. Klimawandel und (Gletscher-) Tourismus. Bedrohte Alpengletscher. Raumordnung 27. Innsbruck.

Gössling-Law, S. \& P. Peeters, 2007. 'It Does Not Harm the Environment!' An Analysis of Industry Discourses on Tourism, Air Travel and the Environment. Journal of Sustainable Tourism 15, 4: 402-417. 
Hennig, S. \& M. Künzl 2005. Toward a Guiding Principle "Recreational Use" The Protected Area Berchtesgaden National Park within the Region. In: Bauch, K. (ed.), 3rd Symposium of the Hohen Tauern National Park for Research in Protected Areas. 15.-17. September 2005, Conference Volume. Kaprun Castle.

Iwand, W.M., J. Radloff \& A. Caterbow (eds.) 2002. Im Dialog TUI - Tourismus und Umwelt. Hannover 2002.

IFO - Institut für Wirtschaftsforschung (ed.) 2000. Verkehrsprognose Bayern 2015. Study conducted on behalf of the Bavarian Ministry of Economy, Transport and Technology.

Meier, R. (no date). Freizeitverkehr - Analysen und Strategien. Berichte des NFP 41 „Verkehr und Umwelt“, Bericht D5. Available at: http://www.nfp41.ch/download/moduld/d5-kf-dt.doc (accessed: 20/07/06)

Permanent Secretariat of the Alpine Convention (ed.) 2007. Report on the State of the Alps. Signals - Special Edition 1, Transport and Mobility in the Alps, Innsbruck, 2007.

Rauh, W., K. Regener \& P. Zellmann 1998. Freizeitmobilität - Umweltverträgliche Angebote und Initiativen. Cit. In: Wessely, H. \& Güthler, A. (eds.) 2004, Alpenpolitik in Deutschland-Anspruch und Realität. Bund Naturschutz Forschung 8, Nürnberg.

Revermann, Ch. \& Th. Petermann 2002. TA-Projek.t Tourismus in Großschutzgebieten - Wechselwirkungen und Kooperationsmöglichkeiten zwischen Naturschutz und Tourismus. Büro für Technikfolgen-Abschätzung beim Deutschen Bundestag, TAB Arbeitsbericht 77, Berlin.

\section{Authors}

Regula Imhof

Born 1969 in Basel. Mother of three, diploma in forestry, managing director of the Liechtenstein Association for Environmental Protection (LGU) for six years; six years' work in Central Asia as deputy program leader and program leader for the Central Asian Mountain Partnership Program (CAMP), since 2007 Vice-Secretary General of the Alpine Convention. The article does not necessarily represent the point of view of the Permanent Secretariat.

Michael Vogel

Dr. Michael Vogel studied and worked with professor H. Remmert. His academic research concentrated on Subantarctica, Antarctica, Feuerland and Patagonia. After periods at the Bavarian Academy for Nature Conservation and Landscape Management (ANL), Laufen/Salzach, and at the Bavarian Ministry for State Development and Environmental Affairs, Munich, he became Managing Director of Berchtesgaden National Park and in 2003 President of ALPARC, the Alpine Network of Protected Areas.

\section{Gérard Ruiz}

Born 1946. Economist specialized in spatial planning, professor of economy, "chargé de mission" for tourism planning, vice-managing director of a structure specialized in sports activities, General Inspector of the French Ministry for Ecology, Energy, Sustainable Development and Spatial Planning specialized in tourism planning, coordinator of an expert group for economic questions on spatial planning within the framework of sustainable development. 